Zeszyty Naukowe Szkoły Głównej Gospodarstwa Wiejskiego w Warszawie

Problemy Rolnictwa Światowego tom 19 (XXXIV), zeszyt 1, 2019: 68-78

DOI: $10.22630 /$ PRS.2019.19.1.6

Dorota Komorowska $^{1}$

Szkoła Główna Gospodarstwa Wiejskiego w Warszawie

\title{
Wyniki produkcyjne i ekonomiczne gospodarstw nastawionych na produkcję zwierzęcą
}

\section{Production and Economic Results of Farms focused on Animal Production}

\begin{abstract}
Synopsis. Celem opracowania jest ocena wyników gospodarowania zasobami produkcyjnymi w gospodarstwach nastawionych na produkcję zwierzęca, które były objęte rachunkowością rolną w systemie FADN w 2016 roku. Analizie poddano wyniki produkcyjne i ekonomiczne oraz produktywność i dochodowość zasobów ziemi, pracy i kapitału gospodarstw nastawionych na chów bydła mlecznego, trzody chlewnej oraz bydła rzeźnego, owiec i kóz. Zaprezentowane w opracowaniu wyniki badanych gospodarstw wskazują na znacznie wyższy poziom wyników produkcyjnych i ekonomicznych oraz efektywności gospodarowania zasobami w gospodarstwach trzodowych, zwłaszcza w odniesieniu do gospodarstw prowadzących chów bydła rzeźnego, owiec i kóz, co wynikało z ich większej skali i intensywności produkcji. Gospodarstwa specjalizujących się w chowie bydła rzeźnego, owiec i kóz uzyskały ujemny wynik ekonomiczny, dlatego dopłaty do działalności tego typu gospodarstw warunkowały ich dodatni wynik końcowy oraz efektywność ekonomiczną gospodarowania zasobami.
\end{abstract}

Słowa kluczowe: produkcja zwierzęca, wyniki produkcji rolniczej, efektywność gospodarowania zasobami w rolnictwie

\begin{abstract}
The aim of the study is to assess the results of managing production resources in farms focused on animal production, which were covered by agricultural accounting in the FADN system in 2016. The analysis covered the production and economic results as well as the productivity and profitability of land, labor and capital resources of farms focused on dairy cattle, swine and slaughter cattle, sheep and goats. The results of the researched farms presented in the study point to a significantly higher level of production and economic results as well as resource management efficiency in pig farms, especially in relation to farms keeping cattle for slaughter, sheep and goats, which resulted from their larger scale and intensity of production. Farms specializing in slaughter of cattle, sheep and goats obtained a negative economic result, therefore subsidies for the operation of such farms were conditioned by their positive final result and economic efficiency of resource management.
\end{abstract}

Key words: animal production, results of agricultural production, resource efficiency in agriculture

JEL Classification: Q12

\section{Wstęp}

W Polsce w ostatnich latach obserwuje się korzystne zmiany w pogłowiu zwierząt i produkcji zwierzęcej. Odnotowano wyhamowanie tendencji spadkowej w pogłowiu

${ }^{1}$ dr hab. inż., Katedra Ekonomiki Rolnictwa i Międzynarodowych Stosunków Gospodarczych SGGW, ul. Nowoursynowska 166,02-787 Warszawa, e-mail: dorota_komorowska@sggw.pl, https://orcid.org/0000-0002-9881-7785 
trzody chlewnej i wzrost pogłowia, do czego przyczynił się wzrost eksportu mięsa wieprzowego. Zwiększyła się liczebność pogłowia wszystkich grup użytkowych bydła, co jest przede wszystkim rezultatem poprawy opłacalności produkcji mleka i żywca wołowego w wyniku wzrostu cen na krajowych i światowych rynkach tych produktów (Rolnictwo..., 2018).

Rozwojowi produkcji zwierzęcej służy postępująca modernizacja i specjalizacja gospodarstw rolnych. Wyniki kolejnego badania struktury gospodarstw rolnych przeprowadzonego przez GUS w 2016 roku $^{2}$, w porównaniu z wynikami uzyskanymi w 2013 r. oraz wynikami Powszechnego Spisu Rolnego z 2010 r., wskazują że przybywa gospodarstw wyspecjalizowanych w produkcji określonych produktów. W 2010 roku do gospodarstw specjalistycznych zaliczono $62,0 \%$ ogółu gospodarstw, w 2013 r. - 69,4\%, a w 2016 r. - 75,7\% (Charakterystyka gospodarstw..., 2014, 2017). Równocześnie zmniejszaniu ulega liczba gospodarstw rolnych zajmujących się produkcją danego produktu, a zwiększaniu skala produkcji poszczególnych produktów.

Specjalizacja gospodarstw rolnych i związany $\mathrm{z}$ nią wzrost skali produkcji to najważniejsze czynniki rozwoju gospodarstw i całego rolnictwa, zwłaszcza w warunkach rozdrobnionej struktury agrarnej (Smędzik, 2010). Produkcja żywca wieprzowego w Polsce jest wciąż nadmiernie rozdrobniona, co stanowi o małej efektywności ekonomicznej dużej części gospodarstw zajmujących się tą produkcją (Borecka, 2016), dlatego producenci żywca wieprzowego powinni zwiększać skalę produkcji (Szymańska i in., 2012, Mirkowska, Ziętara, 2015). Produkcja w większych stadach pozwala osiaggać korzyści z ekonomiki skali, co ma istotne znaczenie w warunkach funkcjonowania na wspólnym rynku przy zbliżonym poziomie cen rynkowych (Hamulczuk, Stańko, 2013). Z danych statystycznych GUS-u wynika, że przeciętne gospodarstwo zajmujące się produkcją żywca wieprzowego zwiększa jej skalę. W 2016 roku na 1 gospodarstwo prowadzące chów trzody chlewnej przypadało 63,8 sztuk tego gatunku zwierząt wobec 39 szt. w 2010 r. (Charakterystyka gospodarstw..., 2014, 2017).

W przypadku produkcji mleka także rośnie przeciętna wielkość stada krów mlecznych (z 6 sztuk w 2010 roku do 8,9 szt. w 2016 r.) (Charakterystyka gospodarstw..., 2014, 2017) oraz wydajność od jednej sztuki w stadzie, co decyduje o rozwoju gospodarstw mlecznych (Ziętara, 2012). Wielkość stada i wydajność mleczna krów determinują poziom kosztów jednostkowych produkcji mleka oraz produktywność i dochodowość gospodarstw mlecznych (Mańko, 2007, Wilczyński, 2012).

Przeprowadzone analizy wskazują na ewidentne korzyści, jakie daje wzrost skali produkcji żywca wołowego. Zróżnicowanie poziomu kosztów produkcji w powiązaniu z wielkością skali jest bardzo wyraźne. Wzrost rozmiaru produkcji sprzyja poprawie jej efektywności, przede wszystkim efektywności ekonomicznej (Skarżyńska, 2009). Z danych GUS-u wynika, że notowana w 2016 r. struktura stada bydła w porównaniu do 2013 i 2010 roku wskazuje na stopniowy wzrost znaczenia chowu bydła w kierunku produkcji żywca wołowego. Potwierdzeniem tego jest również wzrost liczby krów mamek w tym okresie. Ponadto w 2016 roku na 1 gospodarstwo prowadzące chów bydła przypadało 17,3 sztuk tego gatunku zwierząt wobec 11 szt. w 2010 r. (Charakterystyka gospodarstw..., 2014, 2017), co wskazuje m.in. na wzrost skali chowu bydła rzeźnego.

\footnotetext{
${ }^{2}$ Badanie struktury gospodarstw rolnych (badanie strukturalne) w zakresie użytkowania gruntów, powierzchni zasiewów, pogłowia zwierząt gospodarskich oraz charakterystyki gospodarstwa rolnego zostało przeprowadzone przez GUS po raz pierwszy w 2005 roku, następnie w 2007, 2013 i 2016 r. w gospodarstwach indywidualnych.
} 


\section{Materiał i metoda badań}

Celem opracowania jest ocena wyników gospodarowania zasobami ziemi, pracy i kapitału w gospodarstwach nastawionych na produkcję zwierzęcą, które były objęte rachunkowością rolną w systemie $\mathrm{FADN}^{3}$ w 2016 roku. W ramach systemu rachunkowości rolnej FADN gospodarstwa rolne są grupowane m.in. według typów produkcyjnych, określanych na podstawie udziału wartości produkcji z poszczególnych działalności W wartości produkcji całkowitej gospodarstwa. W ich obrębie są m.in. typy: krowy mleczne, trzoda chlewna, zwierzęta trawożerne, czyli gospodarstwa specjalizujące się odpowiednio w chowie krów mlecznych, trzody chlewnej oraz bydła rzeźnego, owiec i kóz. Wyszczególnione typy gospodarstw są przedmiotem analizy porównawczej w niniejszym opracowaniu. W analizie nie uwzględniono gospodarstw wyspecjalizowanych $\mathrm{w}$ chowie drobiu ze względu na brak powiązania $\mathrm{z}$ potencjałem ziemi $\mathrm{w}$ gospodarstwie. Zgodnie z założeniami obowiązującego systemu rachunkowości rolnej, badaniem zostały objęte tylko gospodarstwa przekraczające minimalny próg wielkości ekonomicznej (tzw. gospodarstwa towarowe) (Goraj, Mańko, 2009) i wszystkie one są przedmiotem tejże analizy.

Według metodyki FADN, wyniki produkcyjne gospodarstw rolnych stanowi kategoria produkcja ogółem, czyli produkcja całkowita, która obejmuje produkcję rolniczą roślinną i zwierzęcą oraz pozostałą produkcję, a także przychody z dzierżawienia ziemi, wynajmu budynków, maszyn, świadczenia usług. Natomiast kategoria dochodowa według tejże metodyki to dochód $\mathrm{z}$ rodzinnego gospodarstwa rolnego, określana w niniejszym opracowaniu w skrócie jako dochód $\mathrm{z}$ gospodarstwa rolnego. Odpowiada dochodowi rolniczemu netto $\mathrm{z}$ uwzględnieniem dopłat do działalności produkcyjnej i inwestycyjnej gospodarstw rolnych. W celu określenia znaczenia dopłat w kształtowaniu poziomu dochodów badanych gospodarstw obliczono dochód z gospodarstwa rolnego bez dopłat oraz dochód z gospodarstwa rolnego z dopłatami.

Efektywność gospodarowania zasobami produkcyjnymi w gospodarstwach rolnych mierzy się odnosząc ujęcie wartościowe efektów produkcyjnych oraz wyniki ekonomiczne gospodarstw do wkładu czynników wytwórczych zaangażowanych w ich uzyskanie (Józwiak, 1998, Kapusta, 2012). Odniesienie odpowiednio wyników produkcyjnych pozwala ocenić efektywność produkcyjną, a wyników ekonomicznych - efektywność ekonomiczną. Odniesienie wartości uzyskanej produkcji do wielkości zasobów ziemi użytkowanych w analizowanych gospodarstwach pozwoliło ustalić produktywność zasobów ziemi. Odniesienie wartości produkcji do wielkości wkładu pracy w jej wytworzenie (wkładu pracy przeliczonego na pełny wymiar czasu pracy) pozwoliło obliczyć produktywność wydatkowanej pracy (ekonomiczną wydajność pracy). Natomiast przeliczenie wartości produkcji na 100 zł zaangażowanego kapitału w procesy wytwarzania porównywanych gospodarstw pozwoliło ustalić produktywność kapitału przypadającą na jego jednostkę. $Z$ kolei odniesienie odpowiednio wyniku ekonomicznego (dochodu z gospodarstwa rolnego z dopłatami) do wkładu zasobów produkcyjnych zaangażowanych w jego uzyskanie pozwoliło ocenić efektywność ekonomiczną gospodarowania zasobami

\footnotetext{
${ }^{3}$ FADN to jednolity system zbierania danych rachunkowych we wszystkich krajach członkowskich UE, służący m.in. do kreowania wspólnej polityki rolnej. W Polsce od 2004 roku IERiGŻ-PIB prowadzi badania rachunkowości rolnej w systemie FADN, określanym jako Polski FADN.
} 
w badanych gospodarstwach (dochodowość zasobów ziemi, wydatkowanej pracy i zaangażowanego kapitału).

\section{Potencjał produkcyjny}

Przeciętna powierzchnia użytków rolnych (UR) w porównywanych typach gospodarstw była największa w gospodarstwach specjalizujących się w chowie krów mlecznych a najmniejsza w gospodarstwach nastawionych na chów bydła rzeźnego, owiec i kóz (tab. 1). Wszystkie gospodarstwa dzierżawiły część powierzchni użytkowanych zasobów ziemi.

W oparciu o dane rachunkowości rolnej FADN z zakresu zasobów pracy gospodarstw rolnych można podać tylko wkład zasobów pracy w procesy produkcyjne gospodarstw, czyli nakłady pracy. $Z$ danych rachunkowych wynika, że roczne nakłady pracy ogółem $\mathrm{w}$ przeliczeniu na pełnozatrudnionego w ciagu roku ( $\mathrm{w} \mathrm{AWU}^{4}$ ) były relatywnie większe w gospodarstwach nastawionych na chów krów mlecznych a mniejsze w gospodarstwach nastawionych na chów bydła rzeźnego, owiec i kóz, ale pracochłonność produkcji (mierzona poziomem nakładów pracy na 1 ha UR) ukształtowała się na zbliżonym poziomie we wszystkich grupach gospodarstw.

Tabela 1. Zasoby produkcyjne porównywanych grup gospodarstw

Table 1. Production resources of comparable farm groups

\begin{tabular}{l|ccc}
\multicolumn{1}{c|}{ Wyszczególnienie } & \multicolumn{2}{c}{ Typ gospodarstwa } \\
& Krowy mleczne & Trzoda chlewna & Zwierzęta trawożerne \\
\hline Liczba gospodarstw & 2749 & 704 & 651 \\
Średnia powierzchnia użytków rolnych [ha] & 21,5 & 20,4 & 17,7 \\
- w tym dzierżawionych [ha] & 5,4 & 4,4 & 3,7 \\
Nakłady pracy ogółem [AWU] & 1,79 & 1,64 & 1,47 \\
- w tym pracy najemnej [AWU] & 0,08 & 0,10 & 0,06 \\
Nakłady pracy ogółem na 1 ha [AWU] & 0,08 & 0,08 & 661956 \\
Aktywa ogółem [zł] & 949833 & 1011913 & 37399 \\
Aktywa ogółem na 1 ha [zł] & 44178 & 49604 & 14,3 \\
Zwierzęta ogółem, w tym: [LU] & 25,3 & 55,1 & 1,6 \\
- krowy mleczne [LU] & 16,1 & 0,1 & 11,4 \\
- pozostałe bydło [LU] & 9,0 & 0,6 & 0,2 \\
- trzoda chlewna [LU] & 0,2 & 54,3 & 0,5 \\
- owce i kozy [LU] & 0,0 & 0,0 & 80,9 \\
Obsada zwierząt ogółem w LU/100ha UR & 117,7 & 270,1 & \\
\hline
\end{tabular}

Źródło: obliczenia własne na podstawie (Wyniki standardowe..., 2017).

Potencjał zasobów kapitałowych gospodarstw rolnych stanowią środki produkcyjne trwałe i obrotowe, których wartość obrazują aktywa ogółem. Zasoby kapitałowe porównywanych grup gospodarstw stanowiły w głównej mierze środki trwałe, w tym

${ }^{4}$ AWU - jednostka przeliczeniowa nakładów pracy według metodyki FADN: 1 jednostka AWU = 2120 godzin pracy ogółem/rok. W nakładach pracy ogółem ujmuje się nakłady pracy własnej rolnika i jego rodziny (FWU) oraz nakłady pracy najemnej (AWU). 
budynki i ich trwałe wyposażenie, maszyny, urządzenia, stado podstawowe zwierząt. Ich wartość w przeliczeniu na 1 ha UR, czyli kapitałochłonność produkcji była największa w gospodarstwach trzodowych a najmniejsza i relatywnie znacznie mniejsza w gospodarstwach specjalizujących się w chowie bydła rzeźnego, owiec i kóz.

Liczba sztuk zwierząt utrzymywanych w badanych typach gospodarstw rolnych była wyraźnie zróżnicowana (liczba sztuk zwierząt wyrażona w jednostkach przeliczeniowych $\mathrm{LU}^{5}$ ). W gospodarstwach trzodowych obsada zwierząt na 100 ha UR była ponad dwukrotnie większa niż $w$ gospodarstwach mlecznych i ponad trzykrotnie niż w gospodarstwach prowadzących chów bydła rzeźnego, owiec i kóz. Gospodarstwa nastawione na produkcję żywca wieprzowego opierały żywienie trzody chlewnej w dużej mierze o pasze pochodzące $\mathrm{z}$ zakupu, dlatego utrzymywały znacznie większą liczbę zwierząt (tab. 1). Udział pasz $\mathrm{z}$ zakupu $\mathrm{w}$ żywieniu trzody chlewnej $\mathrm{w}$ tychże gospodarstwach wyniósł ponad $60 \%$.

Tabela 2. Intensywność produkcji porównywanych gospodarstw

Table 2. Intensity of production in comparable farms

\begin{tabular}{l|ccc}
\hline \multirow{2}{*}{ Wyszczególnienie } & \multicolumn{3}{|c}{ Typ gospodarstwa } \\
& Krowy mleczne & Trzoda chlewna & Zwierzęta trawożerne \\
\hline Koszty materiałowe [zt/ha] & 3898 & 8498 & 2221 \\
Koszty ogółem $[\mathrm{zz} / \mathrm{ha}]$ & 5419 & 10264 & 3405 \\
\hline
\end{tabular}

Źródło: jak w tab. 1.

Gospodarstwa nastawione na chów trzody chlewnej prowadziły intensywną działalność produkcyjna, na co wskazuje poziom kosztów ogólem, a także kosztów materiałowych (tj. pośrednich wg metodyki FADN) w przeliczeniu na 1 ha UR (Goraj, Mańko, 2009; Mirkowska, Ziętara, 2015) (tab. 2). Wysoki poziom intensywności produkcji $\mathrm{w}$ analizowanych gospodarstwach trzodowych wiązał się z żywieniem trzody chlewnej paszami pełnoporcjowymi. Ponadto gospodarstwa te opierały żywienie trzody chlewnej $\mathrm{w}$ dużej mierze o pasze pochodzące z zakupu, a pasze pochodzące z zakupu są droższe od pasz produkowanych we własnym gospodarstwie (Borecka, 2016).

Gospodarstwa nastawione na chów bydła rzeźnego, owiec i kóz charakteryzowały się relatywnie niską intensywnością produkcji co wynikało z żywienia zwierząt w głównej mierze paszami objętościowymi w systemie wypasowym.

\section{Wyniki produkcyjne i produktywność czynników wytwórczych}

W związku z tym, że intensywność produkcji w gospodarstwach nastawionych na chów trzody chlewnej była ponad dwukrotnie większa niż w gospodarstwach nastawionych na produkcję mleka i prawie czterokrotnie niż w gospodarstwach prowadzących chów bydła rzeźnego, owiec i kóz to poziom wyników produkcyjnych był także wyraźnie wyższy

${ }^{5} \mathrm{LU}$ - jednostka przeliczeniowa zwierząt według metodyki FADN, równoważna 1 krowie mlecznej lub wybrakowanej albo bykowi w wieku 2 lata i więcej. 
w tych gospodarstwach, zwłaszcza w porównaniu do gospodarstw prowadzących chów zwierząt trawożernych (ponad czterokrotnie).

Wartość produkcji ogółem w gospodarstwach trzodowych kształtowała przede wszystkim produkcja żywca wieprzowego, która stanowiła ponad $75 \%$ wartości produkcji całkowitej, w gospodarstwach mlecznych produkcja mleka, która stanowiła odpowiednio $67 \%$, a w gospodarstwach nastawionych na chów bydła rzeźnego, owiec i kóz produkcja żywca wołowego - ponad $51 \%$. W gospodarstwach prowadzących chów bydła rzeźnego, owiec i kóz produkcja żywca baraniego i koziego miała niewielki udział - 1,2\%, natomiast produkcja mleka stanowiła prawie $13 \%$. W wynikach produkcyjnych gospodarstw mlecznych produkcja żywca wołowego miała ponad 16\% udziału (tab. 3 ).

Tabela 3. Wartość i struktura produkcji porównywanych grup gospodarstw

Table 3. Production value and structure of compared farm groups

\begin{tabular}{|c|c|c|c|}
\hline \multirow{2}{*}{ Wyszczególnienie } & \multicolumn{3}{|c|}{ Typ gospodarstwa } \\
\hline & Krowy mleczne & Trzoda chlewna & Zwierzęta trawożerne \\
\hline & \multicolumn{3}{|c|}{ Wartość produkcji [zł] } \\
\hline Produkcja ogółem & 139434 & 250962 & 52040 \\
\hline Produkcja roślinna, w tym: & 21437 & 56163 & 14739 \\
\hline - zboża & 14885 & 45658 & 10044 \\
\hline - ziemniaki & 1644 & 1216 & 1403 \\
\hline - uprawy pastewne & 3193 & 689 & 1987 \\
\hline Produkcja zwierzęca, w tym: & 117322 & 193861 & 35713 \\
\hline - mleko & 93327 & 530 & 6679 \\
\hline - żywiec wieprzowy & 582 & 189490 & 519 \\
\hline - żywiec wołowy & 22552 & 1830 & 26629 \\
\hline \multirow[t]{2}{*}{ - żywiec barani i kozi } & 0 & 0 & 601 \\
\hline & \multicolumn{3}{|c|}{ Struktura wartości produkcji [\%] } \\
\hline Produkcja ogółem & 100,0 & 100,0 & 100,0 \\
\hline Produkcja roślinna, w tym: & 15,4 & 22,4 & 28,3 \\
\hline - zboża & 10,7 & 18,2 & 19,3 \\
\hline - ziemniaki & 1,2 & 0,5 & 2,7 \\
\hline - uprawy pastewne & 2,3 & 0,3 & 3,8 \\
\hline Produkcja zwierzęca, w tym: & 84,1 & 77,2 & 68,6 \\
\hline - mleko & 66,9 & 0,2 & 12,8 \\
\hline - żywiec wieprzowy & 0,4 & 75,5 & 1,2 \\
\hline - żywiec wołowy & 16,2 & 0,1 & 51,2 \\
\hline - żywiec barani i kozi & 0,0 & 0,0 & 1,2 \\
\hline
\end{tabular}

Źródło: jak w tab. 1.

Wartość produkcji zwierzęcej w przeliczeniu na 1 sztukę przeliczeniową LU była największa w gospodarstwach mlecznych - 4646 zł/LU, najmniejsza w gospodarstwach nastawionych na chów bydła rzeźnego, owiec i kóz - 2503 zł/LU, a w gospodarstwach trzodowych ukształtowała się na poziomie $3521 \mathrm{zł} / \mathrm{LU}$.

Odniesienie wyników produkcyjnych porównywanych gospodarstw do wkładu czynników wytwórczych zaangażowanych w ich uzyskanie pozwoliło obliczyć produktywność zasobów ziemi, pracy i kapitału analizowanych grup gospodarstw (tab. 4). 
W związku z tym, że gospodarstwa specjalizujące się w produkcji żywca wieprzowego uzyskały znacznie wyższy poziom wartości produkcji ogółem niż pozostałe gospodarstwa to efektywność produkcyjna ich czynników wytwórczych także ukształtowała się na znacznie wyższym poziomie, zwłaszcza produktywność zasobów ziemi i pracy w odniesieniu do gospodarstw prowadzących chów bydła rzeźnego, owiec i kóz - ponad czterokrotnie wyższym, a w porównaniu do gospodarstw mlecznych - wyższym o ponad $80 \%$. Produktywność kapitału gospodarstw trzodowych była ponad trzykrotnie większa niż gospodarstw nastawionych na chów bydła rzeźnego, owiec i kóz i prawie o 70\% większa niż gospodarstw nastawionych na chów bydła mlecznego.

Tabela 4. Produktywność zasobów analizowanych gospodarstw

Table 4. Resource productivity in analyzed farms

\begin{tabular}{l|ccc}
\hline \multicolumn{1}{c|}{ Wyszczególnienie } & \multicolumn{2}{c}{ Typ gospodarstwa } \\
& Krowy mleczne & Trzoda chlewna & Zwierzęta trawożerne \\
\hline Produktywność ziemi [zł/ha] & 6485 & 12302 & 2940 \\
Ekonomiczna wydajność pracy [zł/AWU] & 77896 & 153026 & 35401 \\
Produktywność na 100 zł aktywów ogółem [zł] & 14,7 & 24,8 & 7,9 \\
\hline
\end{tabular}

Źródło: jak w tab. 1.

\section{Wyniki ekonomiczne i dochodowość czynników wytwórczych}

Dochód z rodzinnego gospodarstwa rolnego stanowi opłatę zaangażowania czynników wytwórczych gospodarstw rolnych w ich procesy produkcyjne. Syntetyczny rachunek wyników ekonomicznych porównywanych grup gospodarstw przedstawiono w tabeli 5 . Gospodarstwa nastawione na chów trzody chlewnej uzyskały znacznie wyższy poziom wyników produkcyjnych niż pozostałe grupy analizowanych gospodarstw, ale ich koszty produkcji były także znacznie większe (ponad trzykrotnie w porównaniu do gospodarstw prowadzących chów bydła rzeźnego, owiec i kóz).

Koszty materiałowe działalności produkcyjnej gospodarstw trzodowych ukształtowały się na ponad dwukrotnie wyższym poziomie niż gospodarstw mlecznych i ponad czterokrotnie wyższym niż gospodarstw prowadzących chów bydła rzeźnego, owiec i kóz, co wynikało przede wszystkim ze znacznie wyższych kosztów pasz oraz większej obsady zwierząt w tych gospodarstwach. Pasze treściwe stosowane w żywieniu trzody chlewnej pochodziły w dużej mierze z zakupu (ponad 60\%). Koszty pasz w gospodarstwach nastawionych na chów trzody chlewnej stanowiły ponad 90\% kosztów materiałowych i prawie $80 \%$ kosztów ogółem.

Koszty amortyzacji środków trwałych ukształtowały się na wyższym poziomie w gospodarstwach specjalizujących się $\mathrm{w}$ produkcji żywca wieprzowego oraz mleka w związku z wyższą wartością środków trwałych w tych gospodarstwach. Pozostałe koszty (zewnętrznych czynników produkcji, podatki i inne opłaty od ziemi, budynków) były najwyższe w gospodarstwach trzodowych, a ujemne saldo podatku VAT było najwyższe w gospodarstwach prowadzących chów bydła rzeźnego, owiec i kóz.

W rezultacie, wyniki ekonomiczne (dochód $\mathrm{z}$ gospodarstwa rolnego bez dopłat) gospodarstw nastawionych na chów trzody chlewnej ukształtowały się na znacznie 
wyższym poziomie niż gospodarstw mlecznych, natomiast gospodarstwa prowadzące chów bydła rzeźnego, owiec i kóz poniosły stratę (uzyskały ujemny wynik ekonomiczny). Dochód przeciętnego gospodarstwa trzodowego wyniósł 41575 zł, mlecznego - 22935 zł, a strata gospodarstw prowadzących chów bydła rzeźnego, owiec i kóz - 8236 zł. Z badań wynika, że w latach 2015-2016 produkcja żywca wołowego nie przynosiła dochodu, gdyż ceny skupu żywca były zbyt niskie i nie pokrywały kosztów jednostkowych jego wytworzenia (Żekało, 2017).

Tabela 5. Rachunek wyników porównywanych gospodarstw

Table 5. Income statement in comparable farms

\begin{tabular}{|c|c|c|c|}
\hline \multirow[t]{2}{*}{ Wyszczególnienie } & \multicolumn{3}{|c|}{ Typ gospodarstwa } \\
\hline & Krowy mleczne & Trzoda chlewna & Zwierzęta trawożerne \\
\hline & \multicolumn{3}{|c|}{ Rachunek wyników [zł] } \\
\hline Produkcja ogółem & 139434 & 250962 & 52040 \\
\hline Koszty materiałowe & 83797 & 173351 & 39305 \\
\hline Koszty amortyzacji & 26219 & 27511 & 15512 \\
\hline Koszty zewnętrznych czynników produkcji & 4571 & 6661 & 2591 \\
\hline Podatki, opłaty & 1085 & 1358 & 1004 \\
\hline Saldo podatku VAT & -827 & -505 & -1864 \\
\hline Koszty ogółem & 116499 & 209387 & 60276 \\
\hline Dochód z gospodarstwa rolnego bez dopłat & 22935 & 41575 & -8236 \\
\hline Dopłaty & 35780 & 27078 & 30695 \\
\hline \multirow[t]{2}{*}{ Dochód z gospodarstwa rolnego z dopłatami } & 58715 & 68653 & 22459 \\
\hline & \multicolumn{3}{|c|}{ Rachunek wyników [zł/ha] } \\
\hline Produkcja ogółem & 6485 & 12302 & 2940 \\
\hline Koszty materiałowe & 3898 & 8498 & 2221 \\
\hline Koszty amortyzacji & 1219 & 1349 & 876 \\
\hline Koszty zewnętrznych czynników produkcji & 213 & 327 & 146 \\
\hline Podatki, opłaty & 50 & 116 & 57 \\
\hline Saldo podatku VAT & -38 & -25 & -105 \\
\hline Koszty ogółem & 5419 & 10264 & 3405 \\
\hline Dochód z gospodarstwa rolnego bez dopłat & 1066 & 2038 & -465 \\
\hline Dopłaty & 1664 & 1327 & 1734 \\
\hline Dochód z gospodarstwa rolnego z dopłatami & 2731 & 3365 & 1269 \\
\hline
\end{tabular}

Źródło: jak w tab. 1

O poziomie wyników końcowych wszystkich typów gospodarstw zadecydował w dużym stopniu poziom dopłat do działalności produkcyjnej oraz inwestycyjnej uzyskiwany przez gospodarstwa rolne. Według metodyki FADN dopłaty do działalności gospodarstw rolnych są ujmowane przy obliczaniu dochodu z gospodarstwa rolnego.

W przypadku gospodarstw nastawionych na chów bydła rzeźnego, owiec i kóz dopłaty pokryły straty $\mathrm{i}$ warunkowały dochód $\mathrm{z}$ gospodarstwa rolnego $\mathrm{z}$ dopłatami na poziomie 22459 zł. Gospodarstwa te uzyskał najwyższe dopłaty w przeliczeniu na 1 ha UR -1734 zł/ha, natomiast najniższe gospodarstwa trzodowe - $1327 \mathrm{z}$ /ha. Dopłaty uzyskane przez gospodarstwa mleczne ukształtowały się na poziomie $1664 \mathrm{zł} / \mathrm{ha}$. 
Udział dopłat w dochodach gospodarstw specjalizujących się w produkcji żywca wieprzowego wyniósł 39,4\%, natomiast w gospodarstwach mlecznych kształtował się na poziomie około 56\%. Relatywnie mniejszy udział dopłat w dochodach gospodarstw nastawionych na chów trzody chlewnej wynikał $\mathrm{z}$ faktu, że skala produkcji żywca wieprzowego w tych gospodarstwach nie była ograniczona powierzchnią ich użytków rolnych (gospodarstwa te bazowały w dużym stopniu na paszach z zakupu w żywieniu trzody chlewnej), więc nie posiadały dużych powierzchni UR objętych dopłatami. Z badań wynika, że udział dopłat w dochodach gospodarstw trzodowych we wcześniejszym okresie (w latach 2004-2006) był niewielki (Józwiak, 2010).

Dopłaty do działalności gospodarstw rolnych mają przeważający udział w dochodach zarówno gospodarstw rolnych w Polsce, jak i pozostałych krajów Unii Europejskiej (Runowski, 2014). Z obserwacji wynika, że w Polsce szczególnie wysoki poziom wsparcia dochodów uzyskiwały gospodarstwa wielokierunkowe oraz nastawione na uprawy polowe (Goraj, Mańko, 2013).

Tabela 6. Efektywność ekonomiczna zasobów porównywanych gospodarstw

Table 6. Economic efficiency of resources in comparable farms

\begin{tabular}{l|ccc}
\hline \multicolumn{1}{c|}{ Wyszczególnienie } & \multicolumn{3}{c}{ Typ gospodarstwa } \\
& Krowy mleczne & Trzoda chlewna & Zwierzęta trawożerne \\
\hline $\begin{array}{l}\text { Dochód z gospodarstwa rolnego na 1 ha UR } \\
\text { [zł/ha] }\end{array}$ & 2731 & 3365 & 1269 \\
$\begin{array}{l}\text { Dochodowość pracy własnej [zł/osobe] } \\
\text { Dochodowość aktywów ogółem [\%] }\end{array}$ & 33641 & 41969 & 15766 \\
\hline
\end{tabular}

Źródło: jak w tab. 1.

Efektywność ekonomiczną gospodarowania zasobami w badanych typach gospodarstw rolnych, czyli dochodowość zasobów ziemi, wydatkowanej pracy i zaangażowanego kapitału ( $\mathrm{z}$ uwzględnieniem dopłat) przedstawiono $\mathrm{w}$ tabeli 6 . W związku z tym, że poziom uzyskanych dochodów był najwyższy w przypadku gospodarstw specjalizujących się w produkcji żywca wieprzowego to wskaźniki efektywności ekonomicznej gospodarowania zasobami były także najwyższe w tych gospodarstwach.

Dochodowość zasobów ziemi i pracy gospodarstw nastawionych na produkcję żywca wieprzowego była ponad dwu- i półkrotnie większa niż gospodarstw prowadzących chów bydła rzeźnego, owiec i kóz i o ok. 25\% niż gospodarstw mlecznych, a dochodowość kapitału gospodarstw trzodowych była większa odpowiednio: dwukrotnie i o ok. 10\%.

\section{Podsumowanie}

Analizowane typy gospodarstw nastawionych na produkcję zwierzęcą różniły się w zakresie wyposażenia w czynniki wytwórcze. Największą powierzchnię użytków rolnych posiadały gospodarstwa specjalizujące się w produkcji mleka, a najmniejszą gospodarstwa prowadzące chów bydła rzeźnego, owiec i kóz. Gospodarstwa mleczne angażowały największe nakłady pracy, a najmniejsze gospodarstwa nastawione na chów bydła rzeźnego, owiec i kóz. W zakresie wyposażenia w środki produkcyjne to wyraźnie wyższej 
wartości kapitał produkcyjny angażowały gospodarstwa specjalizujące się $\mathrm{w}$ produkcji żywca wieprzowego oraz mleka, zwłaszcza żywca wieprzowego.

Gospodarstwa nastawione na chów trzody chlewnej utrzymywały znacznie większą liczbę zwierząt i prowadziły znacznie bardziej intensywną działalność produkcyjną, co wiązało się z żywieniem trzody chlewnej paszami pełnoporcjowymi, które w dużej mierze pochodziły z zakupu. W efekcie gospodarstwa trzodowe uzyskały znacznie wyższy poziom wyników produkcyjnych, ale także ekonomicznych, zwłaszcza w odniesieniu do gospodarstw prowadzących chów bydła rzeźnego, owiec i kóz. W związku z tym gospodarstwa trzodowe przewyższały pozostałe grupy gospodarstw w zakresie zarówno efektywności produkcyjnej jak i ekonomicznej, zwłaszcza w gospodarowaniu zasobami ziemi oraz pracy.

Gospodarstwa nastawione na chów bydła rzeźnego, owiec i kóz charakteryzowały się niską intensywnością produkcji i uzyskały ujemny wynik ekonomiczny, dlatego dopłaty do działalności tego typu gospodarstw warunkowały ich dodatni wynik końcowy oraz efektywność ekonomiczną gospodarowania zasobami.

\section{Literatura}

Borecka, A. (2016). Produkcja żywca wieprzowego w gospodarstwach rodzinnych w warunkach zrównoważonego rozwoju (Production of live pigs on family farms in conditions of sustainable development). Roczniki Naukowe Stowarzyszenia Ekonomistów Rolnictwa i Agrobiznesu,18(6), 17-21.

Charakterystyka gospodarstw rolnych w 2013 r. (Characteristics of farms in 2013). GUS, Warszawa, 2014.

Charakterystyka gospodarstw rolnych w 2016 r. (Characteristics of farms in 2016). GUS, Warszawa, 2017.

Goraj, L., Mańko, S. (2013). Analiza sytuacji ekonomicznej towarowych gospodarstw rolnych w latach 2004-2010 (Analysis of the economic situation of commercial farms in 2004-2010). Powszechny Spis Rolny 2010, GUS, Warszawa.

Goraj, L., Mańko, S. (2009). Rachunkowość i analiza ekonomiczna w indywidualnym gospodarstwie rolnym (Accounting and economic analysis in an individual farm). Centrum Doradztwa i Informacji Difin, Warszawa.

Hamulczuk, M., Stańko, S. (2013). Uwarunkowania zmian cen wieprzowiny i dochodów producentów trzody chlewnej w Polsce (Determinants of changes in pork prices and income of pig producers in Poland). Zagadnienia Ekonomiki Rolnej, 3(336), 44-66.

Józwiak, W. (2010). Polskie gospodarstwa rolnicze w pierwszych latach członkostwa - kwestie efektywności i konkurencyjności (Polish farms in the first years of membership - issues of efficiency and competitiveness). Ekonomiczne i społeczne uwarunkowania rozwoju Polskiej Gospodarki Żywnościowej po wstapieniu Polski do Unii Europejskiej, 181, IERiGŻ-PIB, Warszawa.

Józwiak, W. (1998). Efektywność gospodarowania w rolnictwie, Encyklopedia agrobiznesu (Efficiency of farming in agriculture, Agribusiness Encyclopedia). Fundacja Innowacyjna, Warszawa.

Kapusta, F. (2012). Agrobiznes (Agribusiness). Centrum Doradztwa i Informacji Difin, Warszawa.

Mańko, S. (2007). Wpływ wielkości stada i wydajności jednostkowej krów na koszty produkcji mleka (The Influence of Herd Amount and Milk Yeld on the Cost of Milk Production). Roczniki Nauk Rolniczych. Seria $G, 93(2), 37-45$

Mirkowska, Z., Ziętara, W. (2015). Sytuacja ekonomiczna i efektywność polskich gospodarstw trzodowych (The economic situation and effectiveness of Polish pig holdings). Zagadnienia Ekonomiki Rolnej, 1(342), 42-56.

Rolnictwo w 2017 r. (Agriculture in 2017). GUS, Warszawa, 2018.

Runowski, H. (2014). Ekonomika rolnictwa - przemiany w gospodarstwach rolnych (The economics of agriculture - changes in farms). W: N. Drejerska (red.), Rolnictwo, gospodarka żywnościowa, obszary wiejskie - 10 lat w Unii Europejskiej, SGGW, Warszawa, 31-48.

Skarżyńska, A. (2009). Opłacalność chowu krów mamek i produkcji żywca wołowego (The profitability of rearing suckler cows and the production of beef livestock). Wiadomości Zootechniczne, 47(3), 25-35.

Smędzik, K. (2010). Problem skali produkcji w różnych typach indywidualnych gospodarstw rolnych w Polsce $\mathrm{z}$ zastosowaniem modeli DEA (Problems of production scale in different types of individual farms in Poland 
using DEA method). Roczniki Naukowe Stowarzyszenia Ekonomistów Rolnictwa i Agrobiznesu, 12(3), 343-348.

Szymańska, E., Hamulczuk, M., Dziwulski, M. (2012). Analiza na temat funkcjonowania sektora wieprzowiny w latach 2004-2010 wraz z prognozą do roku 2020 (Analysis on the functioning of the pork sector in 20042010 together with the forecast by 2020). SGGW, Warszawa.

Wilczyński, A. (2012). Wielkość stada krów a koszty i dochodowość produkcji mleka (Impact of dairy herd size on milk production costs and profit). Roczniki Nauk Rolniczych. Seria G, 99(1), 70-80.

Wyniki standardowe 2016 uzyskane przez gospodarstwa rolne uczestniczace w Polskim FADN (Standard 2016 results obtained by agricultural holdings participating in the Polish FADN). Warszawa, 2017. Pobrano z: www.fadn.pl.

Ziętara, W. (2012). Organizacja i ekonomika produkcji mleka w Polsce, dotychczasowe tendencje i kierunki zmian (Organisation and the Economics of Milk Production in Poland, Trends in the Past and Future). Roczniki Nauk Rolniczych. Seria G, 99(1), 43-57.

Żekało, M. (2017). Produkcja koszty i dochody z wybranych produktów rolniczych w 2016 roku na tle 2015 roku (Production costs and income from selected agricultural products in 2016 against the background of 2015). W: I. Augustyńska (red.), Produkcja koszty i dochody z wybranych produktów rolniczych w latach 20152016, IERiGŻ-PIB, Warszawa, 66-70.

Do cytowania / For citation:

Komorowska D. (2019). Wyniki produkcyjne i ekonomiczne gospodarstw nastawionych na produkcje zwierzęca. Problemy Rolnictwa Światowego, 19(1), 68-78; DOI: 10.22630/PRS.2019.19.1.6

Komorowska D. (2019). Production and Economic Results of Farms focused on Animal Production (in Polish). Problems of World Agriculture, 19(1), 68-78; DOI: 10.22630/PRS.2019.19.1.6 